\title{
Discussion and Analysis on Public-Private-Partnership Industry Fund Mode under New Urbanization Background
}

\author{
Fang Long \\ Institute of Industrial Economics, Jinan University, Guangzhou, China \\ Email: 1181084075@qq.com
}

Received 22 January 2016; accepted 18 February 2016; published 24 February 2016

Copyright (C) 2016 by author and Scientific Research Publishing Inc.

This work is licensed under the Creative Commons Attribution International License (CC BY).

http://creativecommons.org/licenses/by/4.0/

c) (i) Open Access

\begin{abstract}
There is larger financing gap in the public facility construction during the promotion of new urbanization in China. It may relieve the difficulty in Public-Private-Partnership project financing through introducing Public-Private-Partnership industry fund mode, flexibly and effectively lead the social capital to engage in the infrastructure construction, and improve the public service efficiency. Based on the feasibility analysis of Public-Private-Partnership industry fund mode, this article has combed the operation ways of Public-Private-Partnership industry fund mode, and proposed the countermeasures for promoting Public-Private-Partnership industry fund mode on account of existing problems on such basis.
\end{abstract}

\section{Keywords}

New Urbanization, Public-Private-Partnership Industry Fund Mode, Feasibility, Mode of Operation, Countermeasures

\section{Introduction}

The new urbanization is a grand strategy that improves the urbanization quality, converts the way of economic growth, adjusts the economic structure, and relates to the overall modern situation. CPC $18^{\text {th }}$ National Congress and the Central Economic Working Conference define that it should integrate the maximum domestic demand motivation of urbanization and the bonus released from the reformation, improve the solid and sustainable development of national economy depending on the new urbanization, and span the trap of middle income. China's urbanization rate has reached $54.77 \%$ till 2014. Based on the development objective of National New Urbanization Planning (2014-2020) released by State Council, Chinese domestic urbanization rate is expected to 
reach $60 \%$ at 2020. The new urbanization construction means the demand on huge capital. At present, the real estate market supply and demand is becoming saturated increasingly, and the financial income depending on the land transfer is also decreased. Meanwhile, the debt of governmental financing platform is expanded, and it has brought serious potential hazard to the liability risk. The public supporting facility construction simply depending on the financial expenditure has not been able to improve the sustainable development of new urbanization. To raise the fund for construction investment in the frame of No. 43 document, the local government continuously releases local governmental bond for financing, and also introduces the social capital in Public-PrivatePartnership frame. With the flexible form and collection of capital, Public-Private-Partnership industry fund mode has solved the difficulty in Public-Private-Partnership project financing, and becomes a new option for the construction financing of local government.

Innovative investment and financing mechanism and attraction of social capital for public infrastructure facility construction have profound practical significance in propelling new urbanization construction. During the promotion of urbanization, Public-Private-Partnership industry fund mode introduces the flexible and innovative market fund, integrates the power of government, enterprise and society, and satisfies the governmental demand on providing public service through initiating the social capital, as well as meets the corporate requirement on return of investment. The promotion and application of Public-Private-Partnership industry fund mode are of great significance to the country to determine the major economic reformation, accelerating the new urbanization construction, improving the national governance ability, and constructing the modern financial system. This text has combed the operation ways of Public-Private-Partnership industry fund mode on the basis of feasibility analysis of Public-Private-Partnership industry fund mode and with the combination of actual case, and proposed the countermeasures for promoting Public-Private-Partnership industry fund mode on account of existing problems on such basis.

\section{Concepts of the New Urbanization and Public-Private-Partnership}

\subsection{The New Urbanization}

Urbanization refers to the process of transforming rural population into urban population. Urbanization rate is an important indicator of the level of urbanization. Urbanization is a process of continuous population to urban agglomeration, which is the historical stage of the industrialization process in the world. In the last stage, although urbanization to promote the social and economic development in China has made great achievements and in urban modernization and the integration of urban and rural areas also made remarkable development, but in a certain period of time or in some areas, urbanization rapid development led to the development of the disorder, large and medium-sized cities on the verge of blind expansion, growing soil and water resources degradation, ecological environment destroyed. In particular, some of the government's lack of awareness of the many constraints of urbanization, and even decision-making errors, result in a lot of problems in the urban environment.

The new urbanization is based on the concept of "urbanization", but both in the target, content and way to be different. There is no unified definition of the new urbanization. The generally accepted definition of the new urbanization is the new process of urbanization based on people's livelihood and sustainable development and quality as the connotation, the pursuit of equality, happiness, transformation, green, health and intensive as the core objective. The aim of the new urbanization is to achieve regional co-ordination and coordination of various, industrial upgrading and transformation of low carbon, ecological civilization and the intensive and efficient, institutional reform and innovation.

\subsection{Public-Private-Partnership}

Public-Private-Partnership (PPP) was first proposed by the British government in 1992, and has been widely used in recent years. Currently, there is no uniform definition of PPP in academic circles, but generally speaking, it can be divided into the broad sense of PPP and the narrow sense of PPP. PPP is a broad sense of the public sector and the private sector to provide public goods or services and the establishment of a variety of cooperative relations, specific can be divided into outsourcing, franchising and privatization of the three categories. Generalized PPP is an agreement between public and private sectors to coordinate resources to achieve their goals through the pursuit of a common goal. PPP of narrow sense refers only to the government and the private sector in the form of joint venture Company to cooperate, revenue sharing, risk sharing. This article uses the PPP generalized understanding. 


\section{Analysis Feasibility and Necessity of PP Industry Fund Mode}

\subsection{Policy Support}

In 2013, Decision of CPC Central Committee on Several Major Issues for All-around Deepening Reformation released by the $18^{\text {th }}$ Third Plenary Session proposed to allow the social capital to involve in the urban infrastructure investment and operation through franchise, which has launched the PPP development. To quicken PPP promotion, in 2014, State Council released the Instruction of State Council on Investment \& Financing Mechanism in Innovative Key Field Encourages Social Investment, to define to establish and complete the government and social capital cooperation (PPP) mechanism, and encourage the social capital to be involved in the public construction. At the same year, National Development and Reform Commission released Infrastructure and Public Utilities Franchise Operation Law (Exposure Draft) to propose that the state encourages and leads the project for franchise operation in the field of infrastructure and public utilities. On account of specific PPP operation, Finance Department released Notice on Issues related to Implementation of Cooperation Demonstration Project and Instruction on Government and Social Capital Cooperation, which has provided the specific policy operation instruction for PPP project. The mode that different provinces and cities introduce industry fund in the practice is also supported by the central governmental policies. In 2015, General Office of the State Council forwarded the notice of Instruction on Promoting Government and Social Capital Cooperation Mode in the Field of Public Service (GBF [2015] No. 42) released by Ministry of Finance, State Development and Reform Commission and People's Bank, which specially indicates that the industry fund under cooperation between Chinese government and social capital contributed led by the central financial authority can improve the availability of project financing as the social capital involvement project. Under the precondition that it encourages the local government to bear limited loss, it initiates and establishes fund with the financial institution with experience in investment management, and attracts more social capital through introducing structural design. At present, the government at all levels positively promote the innovative financing mode that PPP introduces industry fund, and related laws and legal regulations also have provided policy basis for PPP industry fund mode.

\subsection{PPP Industry Fund Mode Realizes Government and Enterprise Win-Win}

1) PPP industry fund mode expands the financing channel of the project.

Firstly, the mode that PPP introduces industry fund can benefit for relieving the difficulty in financing for new urbanization construction project. At present, on account of continuously expanded risk in liabilities of local governmental financing platform, the central government has released No. 43 document and new budget act to enhance the regulatory management on local governmental financing platform and its debt, so as to greatly restrict the traditional financing channels of local government. The new urbanization construction requests enormous investment, which is impossible to rely on financial fund only. PPP industry fund mode in flexible form can improve the service efficiency, propel to improve and transform the public infrastructure and public service from expansion in supply and demand to benefit and quality through introducing social capital, market competition mechanism, innovative management concept and means, and better satisfy the public demand.

2) PPP industry fund mode optimizes the financing structure of the project

At present, the main domestic PPP financing modes include creditor's right financing and stock equity financing. The creditor's right financing is also called bond financing, which is a kind of financing way that applies the corporate external fund with payment, and the bank loan is the typical one. The stock equity financing refers to the financing that the corporate shareholder is willing to transfer part of corporate ownership, and introduces the new shareholder through capital increment of company. The liabilities of creditor's right financing will be reflected on the Balance Sheet of the project company, while the excessive liabilities rate will make the company hard to continuously raise the new capital and cannot meet the project demand on fund. The stock equity financing requests the investor has high ability in investment judgment, and also has complicated withdrawal mechanism. Compared with the traditional creditor's right financing and stock equity financing, firstly, the fund offered by PPP industry fund is not requested to reflect on Balance Sheet of the project company to avoid the influence on the corporate re-financing and optimize the project financing structure. Secondly, PPP industry fund has flexible withdrawal way, which may be withdrawn through transfer of stock equity, buy-back and listing [1]. Thirdly, the industry fund has professional and senior investment management team and the entire instruction that makes use of PPP project. Finally, PPP industry fund may satisfy the investment demand at all levels, and realize the reasonable distribution of risk and earnings through structural design of superior prior 
to inferior.

\subsection{PPP Industry Fund Makes the Social Capital Share the New Urbanization Achievement}

At present, China is speeding up the new urbanization construction, thus it is not practical to invest financial expenditure as huge construction capital. The new urbanization construction could encourage various social capitals to providing public service through PPP industry fund mode. The active promotion of PPP industry fund mode can break the monopoly, introduce market competition mechanism, and also enable to smooth the investment channels of social capital, and increase the opportunities for social capital investment. Meanwhile, the governmental subsidy, governmental purchase service and other financial institutional arrangements in PPP mode form the stable and reasonable profit expectation of social capital, and enable the social capital can share the success of new urbanization construction.

\section{Operation of PPP Industry Fund}

\subsection{Organization Form of Industry Fund}

The industrial investment fund is also called industry fund, which means to establish the fund company through releasing fund shares to the investor. The fund administrator manages the fund capital, and authorizes the fund trustee to mandate the fund assets for entrepreneurship investment, assets reorganization investment and infrastructure construction investment. At present, it is classified according to the organization form, and the industry fund can be divided to be corporate-type fund, contractual-type fund and limited partnership-type industry fund [2]. The corporate-type fund is established based on the company law, and collects the capital for investment through releasing fund shares. The contractual-type fund releases the earnings voucher to organize the investment fund based on the trust contract. The limited partnership-type industry fund is composed by GP and LP, and has the advantage different from corporate-type fund that the corporate income tax is not required. LP invests less on the industry fund, but has the unlimited liability as the fund administrator, and the income connects with the fund profit, which stimulates the fund administrator to improve the own professional management ability. The contribution of industry fund mainly comes from LP. However, it is different from GP that LP does not participate in the fund management and only assumes the limited liability and share the priority principal and earnings dividend. The structural design of limited partnership-type fund complies with the risk and earnings matching principle, and effectively prevents against the moral risk. At present, the industry fund is generally in limited partnership-type fund.

\subsection{Investment Object of PPP Industry Fund}

During the new urbanization construction process, PPP industry fund mainly invests on the infrastructure and public utilities. In general, PPP industry fund will select the investment objects with clear project objective and output, defined project service object and regional scope, mature and stable project technology, long-term and sustainable operating project and large construction investment scale that mainly depend on the user's payment. The main factor relies that, it is hard to define whether the project output is not convenient for governmental and social public supervision. The rapid change of project technology means that it contains higher technology and policy risk. The simple public welfare project without charging mechanism and the return on investment of social capital that mainly depends on the governmental subsidy will increase the financial burden. In general, the projects that satisfy the investment conditions of PPP industry fund mainly have the following features: relatively flexible price adjustment mechanism, relatively high marketization degree, relatively large investment scale and long-term and stable demand [3].

\subsection{Originated Mode of PPP Industry Fund}

At present, during the acceleration of new urbanization construction, each city positively brings out PPP industry investment fund in various modes. It is classified according to the different fund initiators, and it may conclude and summarize three initiation ways. With the combination of structural diagram, it is explained such three initiation ways as follows.

1) PPP industry investment fund mode with the provincial government as fund initiator 
The provincial government contributes to establish guidance fund as fund initiator, so as to attract the financial institution to contribute to establish industry fund of funds. Upon approval of the project applied by different governments, the contribution made by fund of funds and financial institution may be considered as priority, while the local governmental finance is considered as inferiority, to establish the sub-fund to invest on the project company [4]. The withdrawal mechanism of priority and inferiority can guarantee the principal and earnings of fund of funds and financial institution. During the period of franchise, the project company is authorized to take charge of the financing, design, construction and operation of infrastructure construction. Upon expiration of franchise, the operated project is completely returned to the government without any liability (see Figure 1).

2) PPP industry investment fund mode with the financial institution as fund initiator

The financial institution initiates to establish the special assets management plan, and set up industry fund with the state-owned enterprise platform. The special assets management is planned to be the priority LP, and the state-owned platform is planned to be the secondary LP. It is established GP or designated the fund management company related to financial institution to be GP. The state-owned platform regularly pays the earnings to the limited partner with priority as agreed, and is responsible for buy-back of interest held by the limited partner with priority when the fund is due, and the local government provides financial interest subsidy guarantee (see Figure 2).

3) PPP industry investment fund mode with the entity capital capable in construction operation as fund initiator

The PPP industry investment fund mode with the entity capital capable in construction operation as fund initiator generally has the GP composed by entity capital and Fund Company designated or subordinated to the financial institution. The financial institution and the entity capital establish the industry fund as priority LP and inferior LP respectively, to investment on the project company in the form of stock equity. The project company obtains the franchise right, reaches an agreement on return mode with the government during the project construction and operation period, and provides guarantee action with governmental financial subsidy (see Figure 3).

\subsection{Operation Process of PPP Industry Fund}

The PPP industry fund operation process is divided into three stages according to the time.

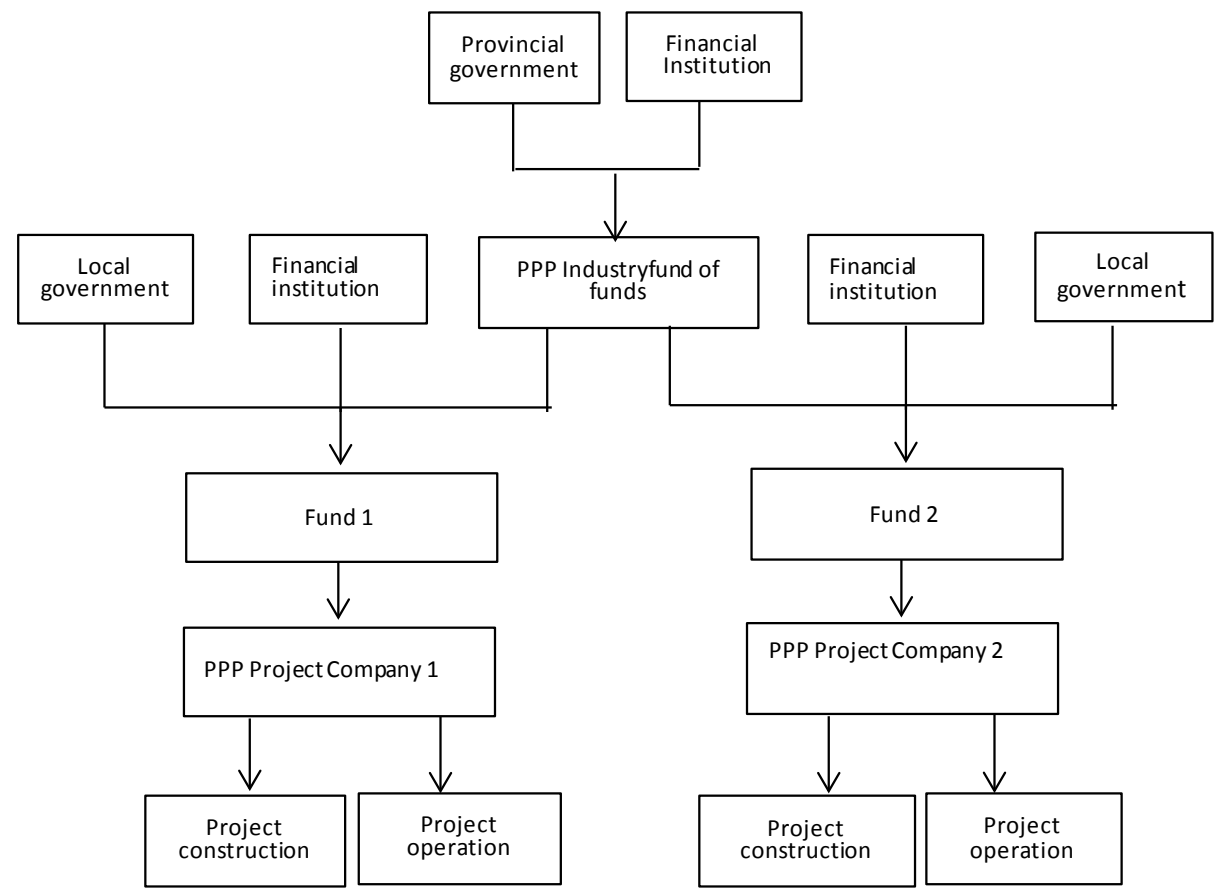

Figure 1. PPP industry investment fund mode with the provincial government as fund initiator. 


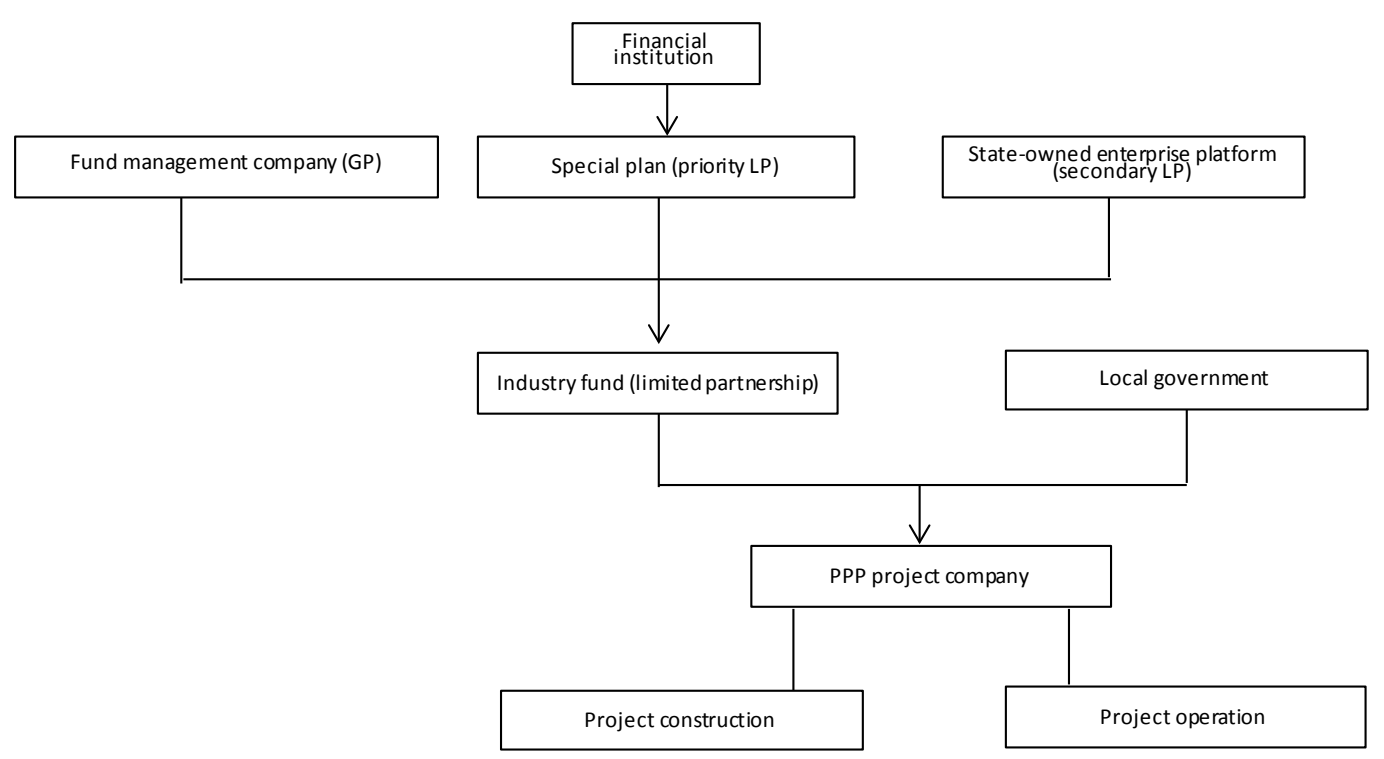

Figure 2. PPP industry investment fund mode with the financial institution as fund initiator.

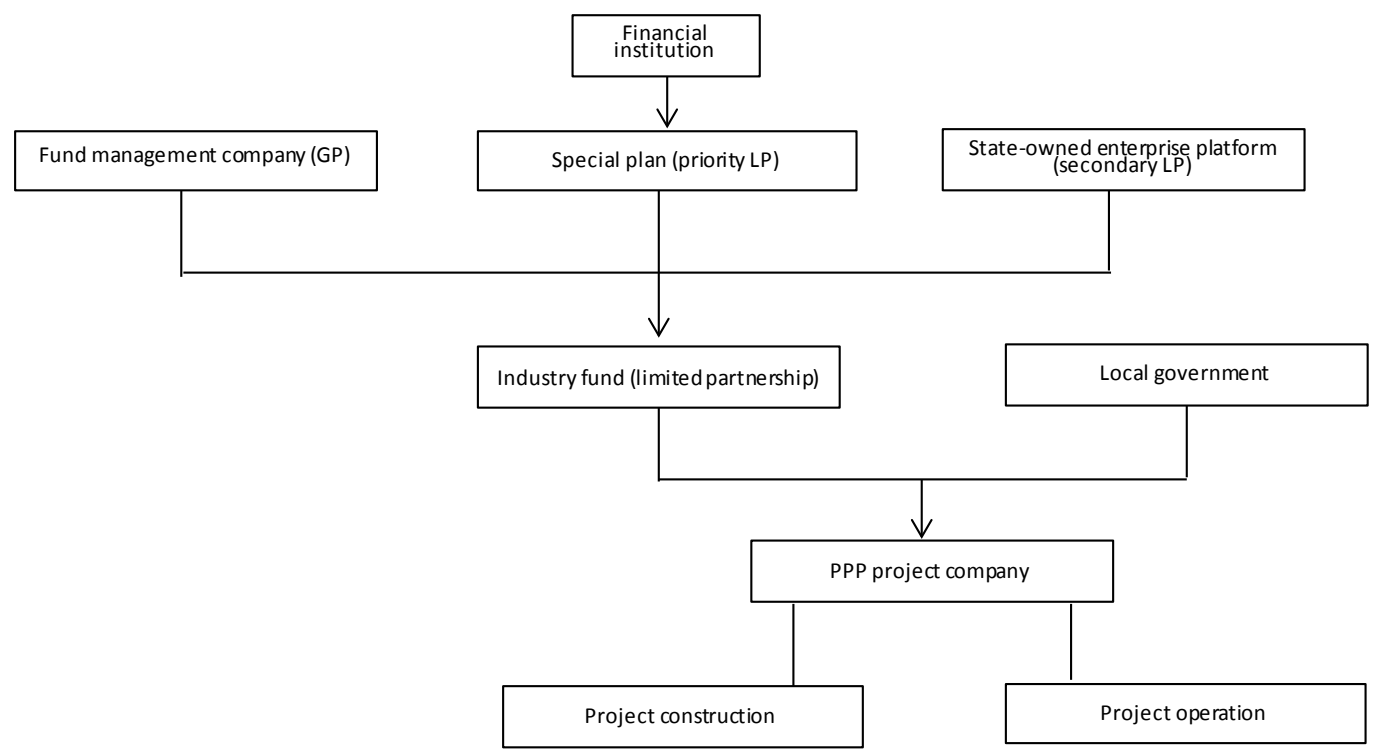

Figure 3. PPP industry investment fund mode with the entity capital capable in construction operation as fund.

1) Stage 1: Project identification and screening stage

PPP project may be initiated by the government and social capital. The governmental initiation means the industrial competent authority selects and recommends the potential project to the financial department from the newly established project, reformation project or storage public assets, while the social capital initiation means that the social capital directly recommends the potential project to the financial department or industrial competent authority through project proposal. In practice, the identification and screening process of PPP project are as follows: the industrial competent authority, subordinated platform company or social capital initiates PPP project and authorizes the local financial authority to report to the provincial PPP center, and then the provincial PPP center makes screening and enters into the databases, which include demonstration database, recommendation database and optional database. During the screening process of PPP project, it should positively refer to the valuable appraisal concept and approach; screen the project which intends to be undertaken in the mode of government and social capital cooperation. In general, the infrastructure and public service project with large in- 
vestment scale, long-term and stable demand, flexible price adjustment mechanism and high marketization degree are appropriate for using PPP mode. PPP industry fund has capital profit-orientation, and the contributor of social capital has strict requirement on the project entered into the database. In the project identification and screening stage, the industry fund gives full play to the risk judgment debility, transfers the risk prevention from the middle and late stage to the early stage of the project, and excludes the project which does not meet the screening condition.

2) Stage 2: Organization and operation of the project company

SPV is generally organized by the union composed by social capital and industry fund. In the project organization stage, PPP implementation plan will reach an agreement on setting of the project transaction structural design, contribution proportion and franchise right, project withdrawal and risk management. In the project operation stage, the project company mainly takes charge of organizing the project construction, and executing the project construction contract with all construction companies. As one of SPV shareholders, PPP industry fund has the power to supervise the project development and operation. Meanwhile, based on the project operation demand on fund, the industry fund may continuously raise the operation capital for subsequent stage at the project operation stage, and provide fund guarantee for the entire project construction. In addition, PPP industry fund also may negotiate with the project initiator for the fund buy-back and withdrawal at the project operation stage.

3) Stage3: Project handover

Upon expiration of franchise, the project company should hand over according to the handover form, handover content and compensation way as stipulated in the project contract. The handover forms include termination of handover upon expiration and advance termination of handover. The compensation ways includes free handover and paid handover. To ensure the project is closed and handed over on schedule, the project company and government should further confirm the handover terms and conditions as stipulated in franchise agreement and formulate the assets appraisal plan in the preparation stage. In the assets appraisal stage, it should appraise the assets conditions and operation status of the project, and make the assets that do not meet the handover conditions maintained by the project company to ensure the quality upon project handover. In the project handover stage, the project company should hand over related intellectual property right, assets checklist and technical instrument as stipulated in the contract, and coordinate to the stable project transition.

\subsection{Withdrawal Mechanism of PPP Industry Fund}

The fundamental purpose and motivation of any investment rely on gaining the return on investment. PPP industry fund withdraws the value-added fund from the invested project through withdrawal mechanism, to realize the mobility of fund capital and value increment of capital, which is a critical point for the operation of PPP industry fund. PPP industry fund has varieties of withdrawal channels, which can be generally classified as follows: Firstly, project mature settlement, which refers to realize the project investment earnings and withdrawal through settling the industry fund upon expiration of project. Secondly, stock equity buy-back or transfer withdrawal, which refers that the industry fund is bought back or transferred to the third party by the project initiator upon completion of project or under proceeding of project, so as to gain the investment earnings and withdrawal through buy-back or transfer. Thirdly, withdrawal of assets securitization, which refers to make certain structural arrangement on the project assets with stable cash flow, so as to separate and reorganize the risk and earnings factor in the assets, and then convert to be the security available-for-sale to gain the project earnings and realize withdrawal [5].

\section{Analysis on the Issues Exist in PPP Industry Fund}

The new urbanization construction originally intends to introduce PPP mode to establish the community relations of interest sharing, risk sharing and entire cooperation, and improve the operation efficiency of the government through introducing social capital and integrating the power of government, corporate and society. Meanwhile, it also establishes the scientific government-corporate relations and compensation mechanism, introduces professional talents and advanced management mode, improves the new urbanization construction, and solves the problems about insufficient investment on governmental public service. In this vision, PPP project introduces the investment form of industry fund stock equity, realizes cooperation of social capital and government, and really shares the risk and interest. 
However, in the actual operation, the industry fund is just considered to be the simple financial investor of PPP project, which is simplified to be a kind of bond financing mode. For No. 43 document restricts the financing of urban investment platform, the local government seek to package the project to be PPP project. The industry fund and local state-owned enterprise or urban investment platform contribute to establish a project company to participate in the infrastructure construction, so as to bypass the financing platform and land storage center which are restricted for borrowing, and form the shadow platform for continuous financing. Such kind of financing mode is also called apparent equity and actual creditor's right. The local government promises to pay fixed income, and make repo-to-maturity and implicit guarantee. Substantially, PPP industry fund has become a kind of bond financing mode, which shows to be off balance sheet financing without increment of local debt, but most of the local finance departments issue the legally ineffective Comfort Letter, and take the income from land transfer as guarantee, which is the creditor's right with the appearance of stock equity. It not only has increased the implicit debt of local government, but also has damaged the stable and sustainable environment necessary for PPP project, and impacted the quality of public service.

\section{Related Recommendation}

\subsection{Properly Recognize PPP Industry Fund Mode}

PPP industry fund is the innovative financing mode of new urbanization construction, but it does not mean that PPP industry fund mode is applied to all public service areas. The local government cannot consider PPP as the cure-all medicine, and also consider the social capital involved in the governmental affairs is included in PPP, and just treat PPP industry fund mode to be the local governmental creditor's right financing way that bypasses the supervision of No. 43 document. In addition, the concept and connotation of PPP also cannot be lessened to be a kind of financing mean that replaces the financing platform. In the actual operation, there is franchise right, scope generalization tendency and other problems. The government should properly recognize PPP industry mode, and form the good cooperation mode with social capital, such as burden sharing, gain sharing and risk sharing. The government should really understand the essence of PPP industry fund, and cannot consider it to be a mean to remove the liability for provision of public service. In the PPP project, it should stick to the contractual spirit, give play to the governmental supervision, and assume the liability for providing financial payment and subsidy for the PPP project with the construction and operation cost unable to be covered by the user's payment and earnings. The successful PPP industry fund mode should be able to effectively introduce more social capital into the governmental public service construction.

\subsection{Complete the System and Policy}

To fully exploit the potential of social capital, attract more social capital to invest on the new urbanization construction, the government should further complete PPP system construction and policy support system, so as to really attain the real policy effect. Relevant national authorities should formulate and complete the standard contract, project facility operation guidance, and related financial management method. Meanwhile different authorities should complete the policy support system, and release PPP project guarantee policy and action on account of special transfer payment, financial tax support, taxation preference and project land guarantee.

\subsection{Enhance the Supervision and Prevent Governmental Default}

PPP industry fund involves huge social capital investment amount and long duration of cooperation, and it should enhance the supervision on PPP project operation procedures, effectively maintain the public interest, and put away the worries of social capital, as well as establish PPP project information platform, realize openness and transparence of PPP project operation and effectively prevent against asymmetric information, rentseeking and governmental default. In addition, it should demonstrate the financial affordability against the governmental payment or PPP project subsidized by the government, to ensure the local government has reliable financial guarantee.

\section{Conclusion}

In the construction of new urbanization, there is a huge investment demand. PPP fund industry will get more and more applications. From the financing needs of PPP projects, this paper proposes the establishment of PPP fund 
industry solutions, analyzes aspects of the establishment of the fund, subject recruitment, investments, exit and mode of operation of the main steps, and makes recommendations for the current PPP fund industry problems, to provide a reference for the future promotion of PPP industry fund.

\section{References}

[1] Xu, S.Y., et al. (2015) Discussion on Investment and Financing Mode of Industry Fund Involved in Public-PrivatePartnership: Taking the Rail Project as an Example. Construction Economy, No. 11, 41-44.

[2] Tan, J.Q. and Cao, Y. (2008) Analysis of Operating Mechanism of Industrial Fund. Finance and Banking, No. 7, 2833.

[3] Zhang, J.Y. (2015) Trust Route through the Public-Private-Partnership Investment in Infrastructure. International Finance, No. 7, 6-12.

[4] Feng, K.W., et al. (2015) Discussion on Establishment and Operation of Public-Private-Partnership Industry Fund under New Urbanization. Construction Economy, No. 5, 5-8.

[5] Gao, L.Y. (2015) Discussion on the Industry Fund the Mode under the Public-Private-Partnership. Economic Forum, No. 8, 69-72. 